\title{
A model for operationalizing ERM in project-based operations through dynamic capabilities
}

Marika Arena, Giovanni Azzone, Enrico Cagno, Amerigo Silvestri and Paolo Trucco

Department of Management, Economics and Industrial Engineering, Politecnico di Milano, Milan, Italy

Corresponding author

Marika Arena can be contacted at: marika.arena@polimi.it

\section{Introduction}

Over the last ten years, enterprise risk management (ERM) has been proposed as a new risk management paradigm, aimed to overcome the traditional approaches to risk management by introducing a holistic system that crosses the entire organization and integrates different units and organizational levels (Arena et al. 2010; Kajuter et al., 2007; Woods, 2007; Power, 2004). This idea of risk management has been rapidly accepted by different economic subjects, including both companies and regulators that agree on the potential benefits of this system for enhancing accountability and governance.

However, the diffusion of this new paradigm also contributed to turn risk management "inside out" making these systems a public and potential disclosable 
matter (Power, 2004, 2007), and establishing a strong connection between ERM and internal controls. Hence, if we look at the cases of ERM implementation, ERM is often confined to the high level governance sphere (Arena et al., 2011; Muralidhar, 2010) and ERMapplications are viewed as a compliance exercise (Collier et al., 2007; Bruce, 2005) or "after-the-fact inspection" activity (Bowling and Rieger, 2005).

This situation could be related to two main problems. On the one hand, the implementation of ERM has to face the existence of pre-existing practices, that result generally more deep-rooted in the organization, in particular in relation to operations management; these practices include supply chain risk management (Trkman and McCormack, 2009), environmental, health and safety risk management (Glendon and McKenna, 1995), project risk management (Zwikael and Sadeh, 2007); IT risk management (Stenzel, 2007). On the other hand, frameworks and standards that have been developed by professional associations and national standard setters (Financial Reporting Council (FRC), 2005; Committee of Sponsoring Organizations (COSO), 2004; AIRMIC, 2002, etc.), usually remain very "high-level". Suggested prescriptions, that are general in scope to be applied to different business processes, often fail to create a shared language and provide instruments that could be used by mangers of different functions to manage their risk.

Moving from these considerations, this paper aims to deploy the idea of ERM into project-based organizations, relying on the concept of capabilities, here conceived as a means by which companies can manage the variability of their performance due to internal and external uncertainties (i.e. threats and opportunities). This concept has been chosen due to its potential of being applied at different organizational levels, to communicate across different organizational units, and being specified locally, to capture the capabilities that are relevant in a certain function/business unit. To achieve this objective, first, a conceptual model, labelled the Spring model, is introduced to highlight how the concept of capabilities could be exploited to represent different risk management strategies. Then, the case study of a leading multinational company competing in the oil and gas industry is used to exemplify the functioning of the proposed model and display the suitability of the concept to operationalize the ERM idea.

The rest of the paper is articulated as follows. The next section introduces the conceptual instruments used in this work: ERM and capabilities. Section 3 outlines the "Spring model" idea and its adaptation to project-based organization. Section 4 describes the role and method for the empirical analysis, whose results are presented in Section 5. Finally, we conclude in Section 6, discussing the implications of this work and the paths for future research.

\section{Conceptual instruments: ERM and capabilities}

In this section, we introduce the two conceptual instruments that are at the basis of the construction of the "Spring model": ERM and capabilities.

ERM definition has been formalised in 2004 by the COSO of the Treadway Commission[1], according to which ERM is:

[...] a process, effected by an entity's board of directors, management and other personnel, applied in strategy setting and across the enterprise, designed to identify potential events that may affect the entity, and manage risk to be within its risk appetite, to provide reasonable assurance regarding the achievement of entity objectives. 
This definition contributes to highlight the two distinctive features of ERM approaches:

(1) comprehensiveness, i.e. ERM aims to cover different risk categories: strategic, operational, financial and compliance risks (Olson and $\mathrm{Wu}, 2007$; Hiles and Barnes, 2001); and

(2) integration, i.e. the management of specific types of risk is not confined within the border of dedicated functions, but all the units within the organizations whose activities could impact on a certain type of risk should be involved in its assessment and management (DeLoach, 2000).

According to ERM proponents, these characteristics allow to overcome the limitations of traditional silo approaches, that assume that risks in different parts of the organization do not influence each other, and therefore can be managed separately (Harrington et al., 2002; Miller, 1998). Following the ERM paradigm, risk is to be identified, analysed and managed transversally to different functions and organizational levels (project, portfolio, function, enterprise).

However, to this aim, a shared language that is valid across the organization is needed, to avoid a misalignment between the governance sphere and technical functions, leading to the introduction of the concept of capabilities and how they can be used to manage risk.

In general, terms, capabilities can be defined as a firm's ability to leverage and transform its resources (Prahalad and Hamel, 1990; King and Tucci, 2002), that are constituted by the tangible and intangible assets owned and controlled by the firm (Amit and Schoemaker, 1993; Hitt et al., 2000). Merely possessing resources does not guarantee the achievement of a defined objective, that have to be pursued through the creation of capabilities to integrate, build, and reconfigure resources in accordance with the evolution of the external context (Hill and Jones, 1992; Teece et al., 1997). Moving from this consideration, capabilities have been conceptualized as different risk response strategies -, i.e. means by which companies can manage the variability of their performance in changing environments (Eisenhardt and Martin, 2000; Teece, 2007), dealing with emerging risks and opportunities (O'Reily and Tushman, 2007).

The literature provides different classifications of capabilities (Ambrosini and Bowman, 2009) and, in this paper, we rely on Teece et al. (1997) and Collis (1994), identifying four different categories of capabilities: delivery, integration and coordination, learning and reconfiguration. Delivery capabilities encompass all the firm capabilities concerning the execution of organizational tasks (Collis, 1994). They include capabilities ranging from the production of goods and services, production scheduling, and monitoring, to controlling. In project-based operations, the expediting and project planning and control processes are typical examples of delivery capabilities. Integration and coordination capabilities aim at supporting the delivery capabilities, managing and coordinating dependencies among resources in order to create new ways of performing a set of activities (Teece et al.,1997). Project portfolio management, human resources management, engineering support and coordination are typical examples of this type of capability. Learning capabilities are instead embedded in and transcend the whole organization (Teece et al., 1997). They represent the process of generating new knowledge to enhance existing resources, improving their efficiency and effectiveness. An example of these capabilities is the firm's ability to set up a quality monitoring 
system to analyse the production process, to obtain feedback and to consolidate lessons learned. Finally, reconfiguration capabilities refer to the ability of reconfiguring the existing resources to re-design operational and organizational competencies (Teece $e$ t al., 1997). Strategy definition, selection of productive centres and the development of strategic partnerships are typical examples of these capabilities.

\section{The "Spring model": managing risk through capabilities}

In this section, we introduce the "Spring model" and we discuss how it could be applied to a project-based organization characterized by different organizational levels (enterprise, project portfolio and operations, encompassing projects and functions).

\subsection{The "Spring model"}

The "Spring model" is conceived as a possible representation of how risk can impact an organization and how capabilities can be used to manage it. The name of the model has been chosen in the light of the role of capabilities that allow an organization to withstand external and internal pressures while continue to achieve its objectives, ensuring the organization's resilience (Välikangas, 2010; Sheffi, 2005; Hamel and Valikangas, 2003). Graphically, this concept is made through the contraction and a controlled release of the springs that represent the company's capabilities, as we discuss as follows.

As shown in Figure 1, the proposed model includes five main elements:

(1) The Initial situation, which is determined by the results achieved by the company so far as well as all the experiences cumulated in the business environment. For example, two companies (e.g. a market leader and an emerging one) may compete in the same context moving from a different initial situation, that implies different threats/opportunities.

\section{Risk Source Classification (COSO)}

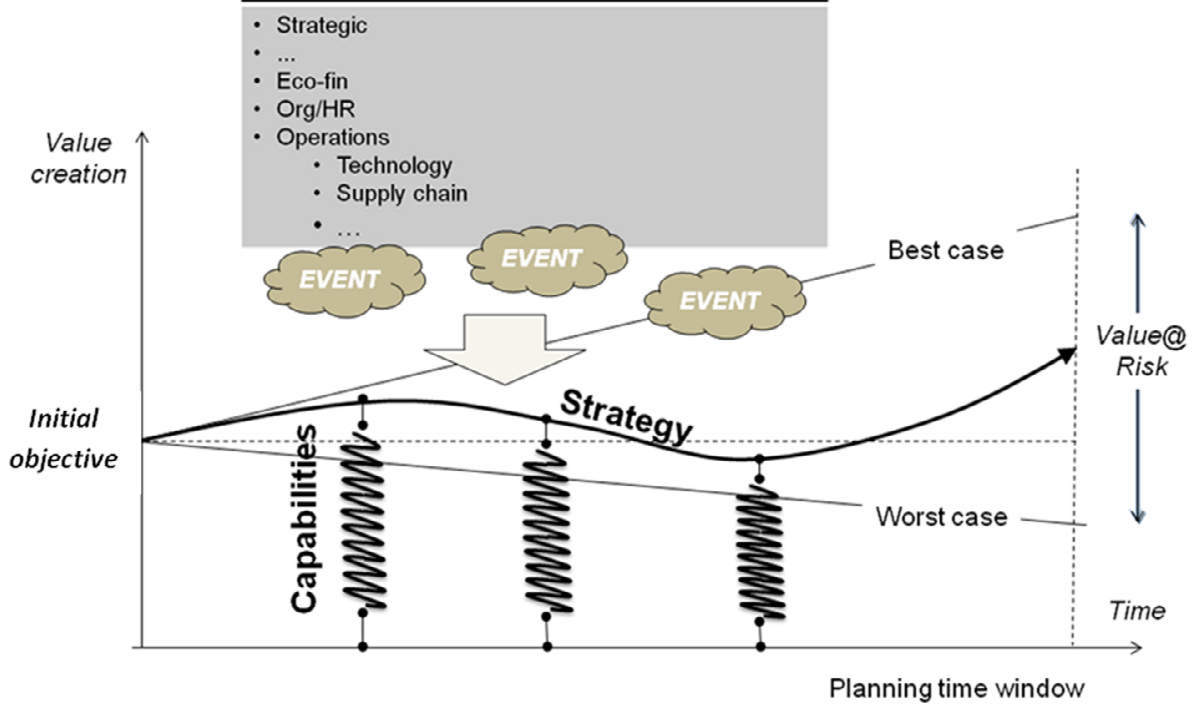

Figure 1. The "Spring model" for ERM 
(2) The Objectives, which represent the targets to be accomplished by the company in the specific time horizon. They can be updated due to the evolution of the internal/external environment.

(3) The Strategy, that is defined as "a combination of the ends (goals) for which the firm is striving and the means (policies) by which it is seeking to get there" (Porter, 1986). In Figure 1, the strategy is represented by a flexible line, whose path should be consistent with the evolution of business environment.

(4) Events, that can be internal and external. They arise from different causes that may impact on a system. Events are represented in Figure 1 with the clouds. The arrows that link the events highlight the interactions that can impact the organization's path. According to ERM literature, we classify events in terms of sources of risk: operative risk, country risk, fraud risk, strategic risk, compliance risk, market risk, resources and organizational risk, financial risk.

(5) Capabilities, that are the tools that can be used to answer to deviations from the strategy and represent the ability to exploit resources in combination with organizational processes in order to achieve the desired effects (Helfat and Lieberman, 2002). They are here represented as "springs" in Figure 1.

When an unexpected event affects the achievement of the company's objective, capabilities can be exploited to face it and stick to the strategy, which is graphically represented through the contraction and a controlled release of the springs as if the objective was under the influence of forces (events) to be absorbed (threats) or exploited (opportunities).

\subsection{The multi-level "Spring model"}

When it comes to apply the "Spring model" to project-based companies, different organizational levels should be taken into consideration, i.e. enterprise, project portfolio and operations, encompassing projects and functions (Figure 2). Though the concept of capabilities is transversal to the entire organization, different capabilities can be used at different organizational levels. Hence, Table I provides a possible classification of different capabilities at enterprise, portfolio, function and project levels, though their actual allocation to the organizational levels depends on managerial decisions.

In this perspective, the overall company's resilience can be declined, distinguishing between (Figure 2):

- Structural resilience, that refers to the inherent capacity of each organizational level to face changes through a set of capabilities available at the same level.

- Organizational resilience, that refers to the capacity to rapidly implement coordinated actions involving the entire chain of actors/resources; it is typical of the whole organization and does not depend on the capabilities available to individual levels.

Accordingly, the multi-level "Spring model" encompasses three possible risk propagation and control mechanisms (Figure 3):

- First, a variation of a given target in a certain level can result in an event affecting another organizational level, requiring the exploitation of organizational resilience. 


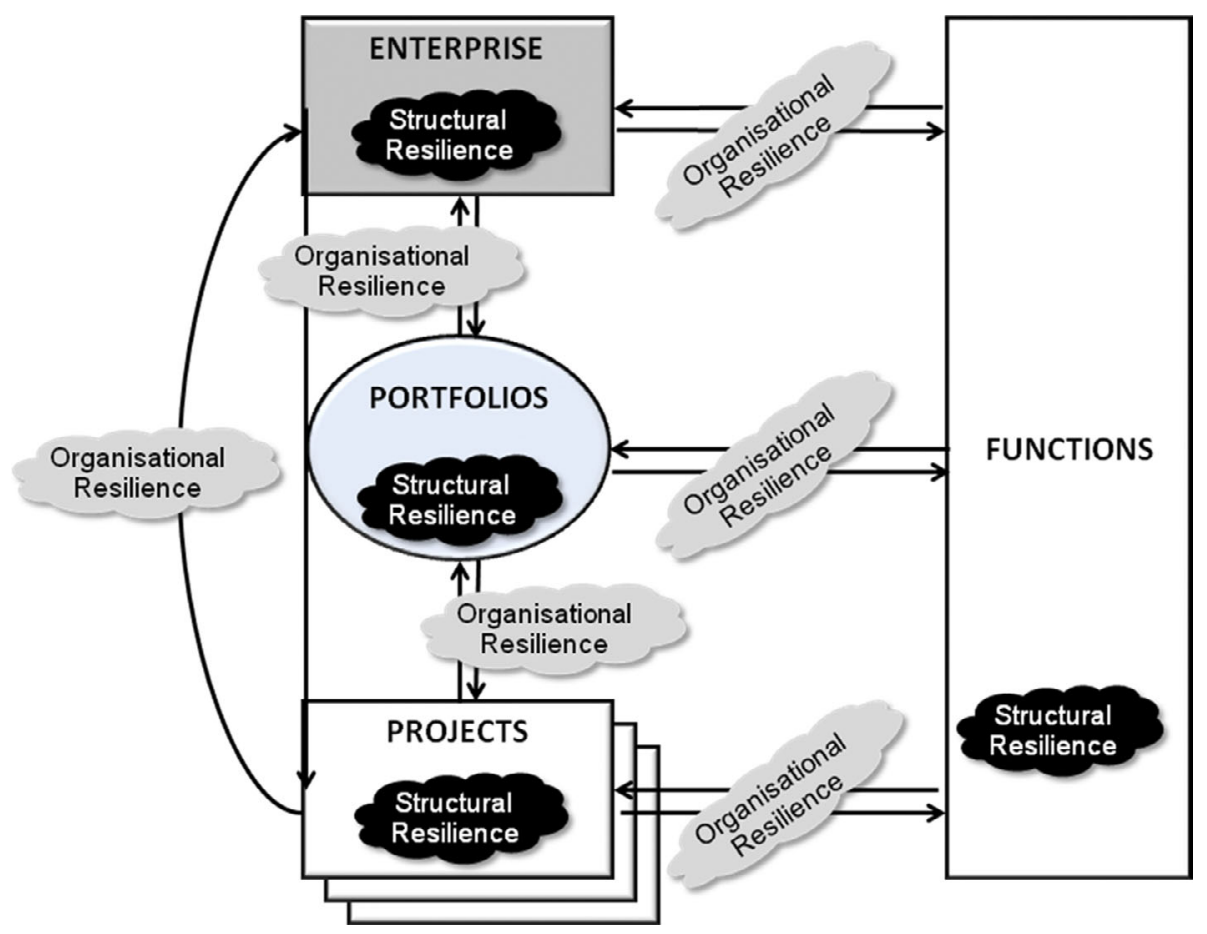

Figure 2.

The multi-level "Spring model" for ERM

\begin{tabular}{ll}
\hline Risk management level & Capability \\
\hline Enterprise & Financial control \\
& Multibusiness coordination \\
& Merger and acquisition \\
Portfolio & Capital expenditure \\
& International management \\
& Asset management \\
Projects & Client management \\
Functions & Business line selection \\
& Contract design \\
& Project architecture \\
& Resource utilization \\
& Systems and technology \\
& Knowledge \\
& Process design \\
\hline
\end{tabular}

Table I.

Classification of ERM capabilities

- Second, the unavailability of a capability in a level could generate an event in another level. Indeed, when a capability is not available, requests for other capabilities (organizational resilience) are needed, looking for the best alternative in terms of trade-off between target change and effect. 
Figure 3.

Risk control options through resilience capabilities

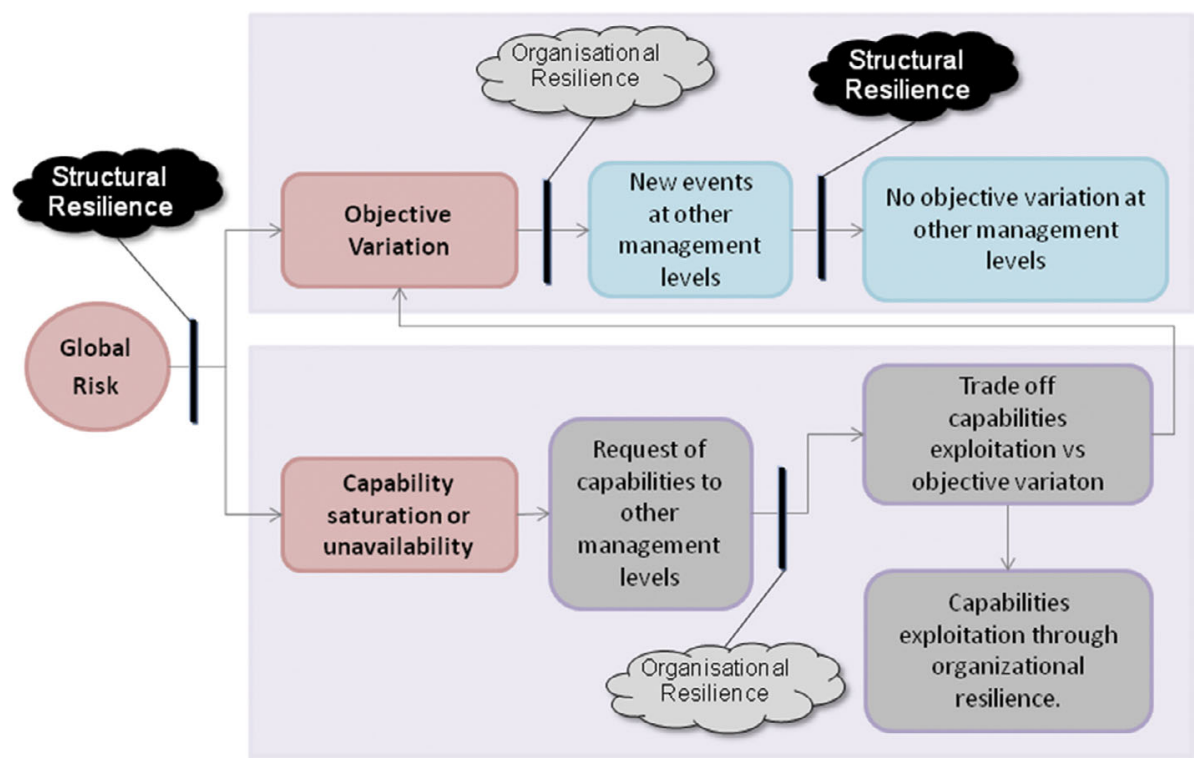

- Third, an event can impact simultaneously on different levels because of the occurrence of a "global risk". The overall risk impacts at various levels as a change in objectives or depletion of several capabilities. To understand the ways in which they propagate within the company, these consequences can be linked to the two interactions described above. The risk control options are activated between the levels on the basis of available resources according to a compensation mechanism.

It is worthy note that there are some events occurring at a specific level with significant impacts, which does not propagate to other levels. In this case it is only observable a propagation of consequences within the level of origin.

\section{Research method: case study}

The empirical analysis, carried out through a case study, aimed to exemplify the functioning of the proposed approach and the potential benefits associated to the adoption of the concept of capabilities in connection to ERM. To this aim, a field study was carried out over a three-year period (from 2008 to 2010) in a company, competing in the oil and gas sector, with a best in class risk management process. In this company, first, the key elements constituting the "Spring model" were identified; second, the occurrence of some paradigmatic risk was studied, to highlight the potential of the proposed approach to support the systematization of existing risk response strategies and the identification of alternative strategies in an integrated fashion.

The chosen organization is a large contractor competing in the oil and gas industry; it provides many different services, including specialised services and maintenance, modification and operations, with a particular focus on technologically challenging projects, such as activities in remote areas, deepwater, gas, and difficult oil. The group has a strong local presence in strategic and emerging areas such as West Africa, 
Former Soviet Union countries, Central Asia, Middle East, North Africa and South East Asia. It employs over 30,000 people, organized into three global business units: onshore, offshore, drilling. In 2008 , revenues amounted to $€ 10$ billion, with operating profit of $€ 1$ billion and the level of new contracts awarded to the group was $€ 14$ billion.

The main risks faced by the group include market, credit, liquidity, operational, country. In 2006, the group established the "risk and opportunity management (ROM)" unit, which aims to support business units in the execution of a project (by providing assistance, advice ...), disseminate a risk management culture, provide adequate training activities and ensure the constant update of corporate guidelines, procedures and standards in the ROM area.

Multiple methods of data collection were employed (Yin, 1994): semi-structured interviews; official documents and presentations; archives; direct observation and internal document usually not available to the public. The primary data sources were face-to-face interviews with key actors in the risk management process at different organizational levels. Overall, 12 different informants were interviewed, including: project managers, internal audit senior vice president (SVP), procurement SVP, project management SVP, risk management VP, operations managers of the different geographical areas, and all the members of three project teams. Most of the informants were interviewed two or more times. The interviews were arranged at the interviewees' respective offices. We developed an interview guide, identifying the main discussion points and questions, but we used it with flexibility, to be able to deepen the issues that emerged during the interview. These interviews lasted approximately 2 hours each. Follow-up issues were raised with interviewees where additional detail or clarification was sought.

We addressed potential informant bias in several ways. First, we interviewed highly knowledgeable informants at multiple hierarchical levels and from multiple parts of the firms. Second, each interviewee was informed that their opinions would be made anonymous and accordingly could be speak freely on their views about the matters in question. Third, we triangulated data from multiple informants and archival sources financial reports, company presentations, organisational charts, reports and working papers.

Finally, data analysis was articulated into two steps. First, we mapped all relevant internal processes and capabilities. To this end, we moved from the generic processes and capabilities of project-based organizations and we produced a complete map through the analysis of the company's procedures and interviews performed. At this stage, we focused on identifying existing capabilities (whether they emerged from the interviews or they were formalized in the analysed documents). Second, we analysed some paradigmatic case of events actually happened, focusing on the risk propagation and control mechanisms and the actual use of a capability in the risk management process.

\section{Case study: multilevel ERM model specification in a leading oil and gas company}

The case study was articulated into two steps:

(1) identification of different components of the model and thorough mapping of all the risk management capabilities available within the organisation at different levels; and 
(2) analysis of the risk propagation mechanisms, based on risks actually occurred in the case study to exemplify the ability of the model to coherently represent how different events may propagate within a project-based organisation depending on structural and organisational resilience performances.

\subsection{Mapping of ERM capabilities}

According to a resource-based view (RBV) of the organization, capabilities were mapped against the company's value chain. To this end, business processes were distinguished between primary processes, which impact directly on clients' satisfaction and on the performance required by the project stakeholders (e.g. commercial management, project management, engineering, procurement, operational activities, and commissioning); ancillary processes which support primary processes in the accomplishment of project and project portfolio objectives (i.e. asset management, organization, ICT, health safety, environmental system, quality systems, human resource management, legal, financial services, administration and control); and management supporting processes, which support the whole organization in the accomplishment of business and compliance objectives (internal audit, M\&A, investor relations, strategy and development, company secretary) (Figure 4).

Moving from the process analysis, the available capabilities were identified by reviewing formal procedures and company's documents and by interviewing key respondents at each organisational level (see the method section for details about data analysis). To build an overall capability map, a distinction was made between (Table II):

Figure 4.

The value chain and organisational levels in EPC companies

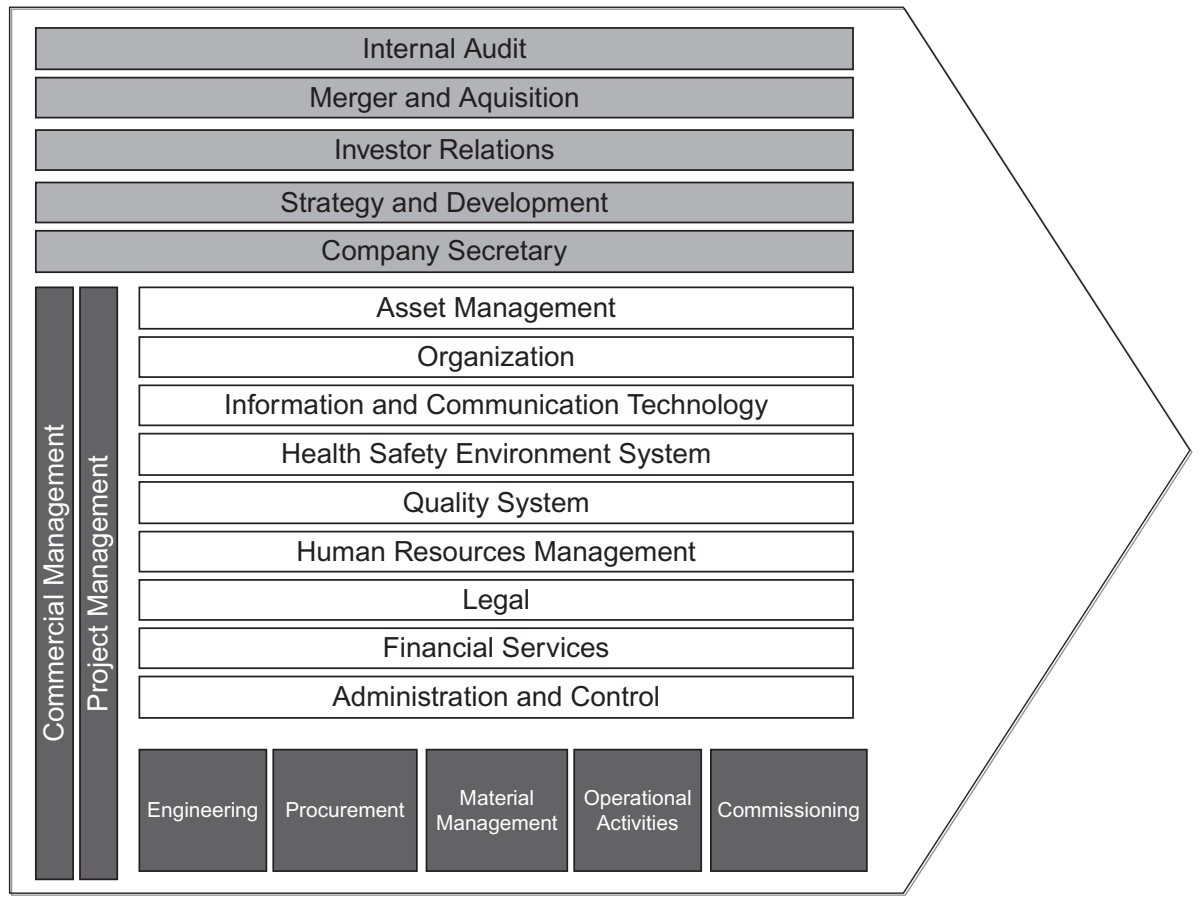




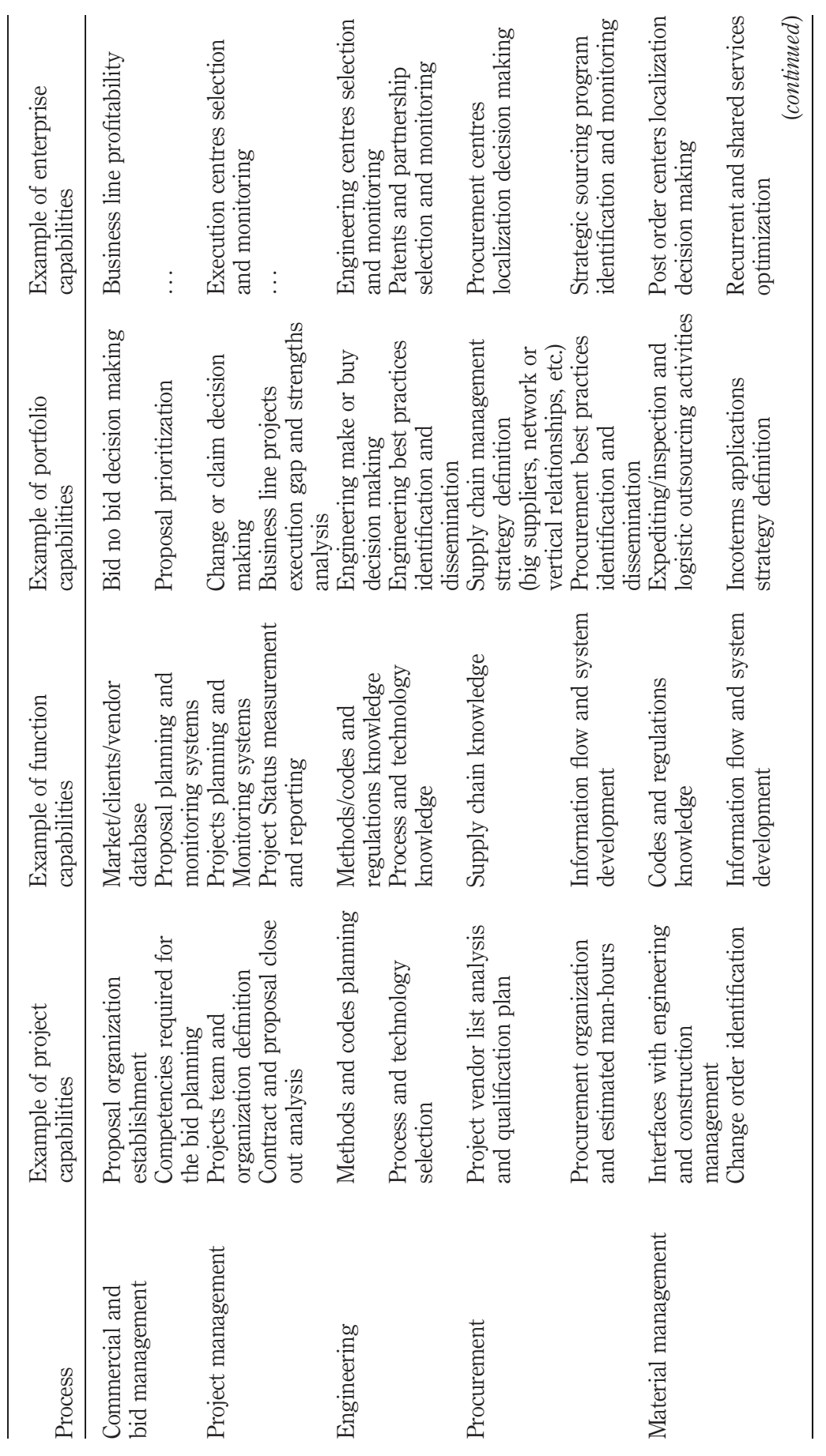

Table II.

Example of typical ERM capabilities identification in project-based organisations 


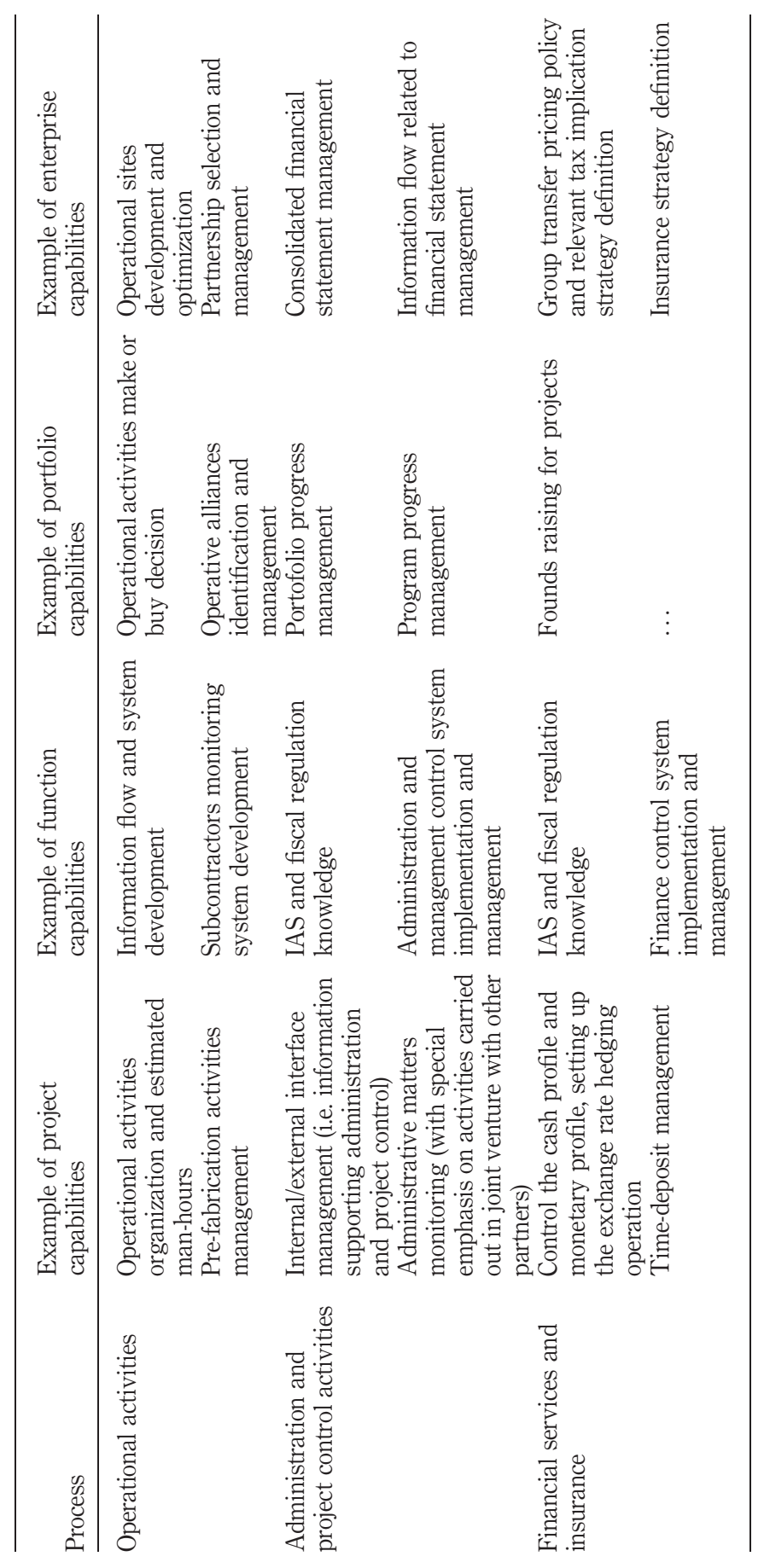


- capabilities established at enterprise level to support executive management in the enhancement of economic value added[2] (EVA) contributing to the financial control, capital expenditure, international management, reputation management;

- capabilities established at project portfolio level to support business management in the enhancement of portfolio backlog and profitability contributing to the assets management, clients relationship management, business line and contractual design;

- capabilities established at project level to support project/proposal management in the accomplishment of project objectives (i.e. scope, time, cost and quality) contributing to the project architecture management, resources management and coordination activities; and

- capabilities established at function to support functional management in the optimization of resources saturation and profitability contributing to the process design, systems and knowledge management.

The number and boundaries of capabilities were sometimes arguable: since no strict methodological prescriptions or recommendations are reported in literature on this regard, we decided to align the final map with the actual view that company's managers have of the overall organisation from a risk management perspective, i.e. what they actually consider capabilities in making their risk-related decisions. The identified risk management capabilities were cross-checked with the risk mitigation measures that were planned or actually implemented as reported in the company's risk register and the final map was returned and validated by the company's managers.

This process leaded to the identification of a total of 465 different capabilities, whose distribution across the four organizational levels, is represented in Table III.

\begin{tabular}{|c|c|c|c|c|c|c|}
\hline Process & Project & Functions & Portfolio & Enterprise & Total & \\
\hline Commercial and bid management & 9 & 12 & 5 & 1 & 27 & \\
\hline Project management & 12 & 10 & 4 & 1 & 27 & \\
\hline Engineering & 15 & 15 & 3 & 3 & 36 & \\
\hline Procurement & 11 & 10 & 4 & 3 & 28 & \\
\hline Material management & 10 & 8 & 4 & 2 & 24 & \\
\hline Operational activities & 16 & 8 & 4 & 2 & 30 & \\
\hline Administration and project control activities & 10 & 10 & 3 & 5 & 28 & \\
\hline Financial services and insurance & 8 & 13 & 2 & 6 & 29 & \\
\hline Legal & 5 & 9 & 1 & 2 & 17 & \\
\hline $\mathrm{HR}$ & 9 & 16 & 3 & 5 & 33 & \\
\hline Organization & 6 & 11 & 2 & 3 & 22 & \\
\hline Quality & 12 & 12 & 2 & 2 & 28 & \\
\hline HSE & 9 & 14 & 2 & 4 & 29 & \\
\hline ICT & 7 & 6 & 1 & 1 & 15 & \\
\hline Assets & 9 & 16 & 3 & 6 & 34 & \\
\hline Internal audit & - & 7 & 1 & 2 & 10 & \\
\hline Company secretary & - & 6 & 1 & 2 & 9 & \\
\hline Business planning and M\&A & - & 9 & 2 & 6 & 17 & Table III. \\
\hline Investor relations & - & 7 & 2 & 4 & 13 & Distribution of ERM \\
\hline Strategy and development & - & 6 & 1 & 2 & 9 & capabilities in the case \\
\hline Total & 148 & 205 & 50 & 62 & 465 & study \\
\hline
\end{tabular}




\subsection{Analysis of the risk propagation and resilience mechanisms}

The second step consisted in the analysis of some risk mitigation measures and the related consequences at different organisational levels, by using the three risk propagation/control mechanisms introduced in the multi-level "Spring model". In the following, three risk items are reported and briefly discussed in relation to an objective variation at project level, the unavailability of a key capability and a global risk impacting on all organisational levels.

(a) Objective variation at project level. The first risk analysed consists into "project delay due to engineering documents approval from the client due to different geographical locations and engineering and procurement reworks".

The risk impacts were evaluated on the basis of the economical impact on the project and the eventual client's dissatisfaction, through the project risk management system. Mitigation actions were addressed among the project organization utilizing the procurement and contract administration capabilities. In addition, an informal warning related to the delay in the vessel mobilization was issued to business unit management. According to the model it was possible to systematically identify other potential impacts as:

- proposal ongoing with the same client are blocked due to client's dissatisfaction at project portfolio level;

- assets unavailability for other projects at project portfolio level;

- resources unavailability for other projects at functions level; and

- engineering centre selection ineffective for future projects at corporate level.

In addition to the capabilities utilized by the project team at project level, different risk control paths were identified in order to manage impacts at all levels, as summarized in Table IV.

For example, at enterprise level the exploitation of "engineering centre selection and monitoring" was identified as available capability to localize engineering centres closer to the client; at portfolio level the "client relationship management" capability was identified as a key action to evaluate possible compensations to the client through other projects; at function level "engineering workload management" and "ICT infrastructure and applications planning" as additional capabilities to mitigate the risk of project delay and the related induced risks.

(b) Capability unavailability or saturation at portfolio level. The second risk analysed is the "awarding of contracts including specific welding activities could be not possible due to unavailability of skilled subcontractors in a specific area".

Table IV.

Potential risk control paths for mitigating the event: "delay of engineering project approval"

\begin{tabular}{lll}
\hline Management level & Process & Capability \\
\hline Function & Engineering & Scope of work identification techniques development \\
Portfolio & ICT & ICT infrastructure planning \\
& Commercial and & Client relationship management \\
& bid management & Engineering best practices identification and \\
Enterprise & Engineering & Engineering centres selection and monitoring
\end{tabular}


Again, risk impacts were evaluated considering the influence on proposals and the potential effect on the commercial plan through the proposal/project risk management system. Mitigation actions were addressed among the proposal organization through the client relationship management and negotiation capabilities in order to exclude the welding activities from the scope of work and improve the competitive advantage of the company. According to the model, it was possible to identify possible opportunities as:

- developing new professional skills exploiting construction competencies available in other areas, at portfolio level;

- developing strategic alliances in the area, at portfolio level;

- developing different welding supervision activities in order to manage not accustomed subcontractors, at functional level; and

- developing local permanent organization in order to directly manage all construction activities, at corporate level.

Furthermore, different risk control options were identified in order to manage impacts at all levels, as summarized in Table V. For example, additional capabilities that could allow to enter the geographical market include the recourse to the "execution centres selection and monitoring" at enterprise level, "business planning for new ventures and partnership" capability at portfolio level and "operations best practice identification and management" at functional level.

(c) Global risk impacting on all organisational levels. In the case of a risk potentially impacting on all the management levels several different risk control options, i.e. combinations of RM capabilities, could be suitable for implementation. To test the risk propagation/control mechanisms comprised in the multi-level "Spring model", the following risk item can be analysed:

[...] project delay due to a supplying of components, which do not respect the design requirements. Such delay will generate problems with the client, who will require penalties for each days of delay, as prescribed in the contract.

The company could perceive the risk as an ordinary problem and use the capability "change order identification" to resend the order, which have then to be monitored by the capability "general terms and condition follow-up for the project procurement activities". Consequently, the firm will interact with the client through the capability "client relationship management", supported by the capability "assistance to manage disputes arising in the contractual relationship with client and/or partner and/or subcontractor" if necessary. In this way the company will realize a strategy relying on capabilities at project level, pursuing a reactive approach. However, this risk mitigation plan is quite static and it does not generate any improvement in the company ERM system to prevent the same occurrence in future.

In particular, the firm could plan a more dynamic approach if, after resending the order through the capability "change order identification", manage it with the capability "procurement progress and deviation management" to foresee and control the new components delivery date. In the mean time, the firm could re-plan the project schedule leveraging on "project planning activities" to postpone as possible the activities requiring the specific components. In such way the company will reduce the risk of project delay. Moreover, the company could pursue an even more proactive approach 


\begin{tabular}{|c|c|c|}
\hline $\begin{array}{l}\text { Management } \\
\text { level }\end{array}$ & Process & Capability \\
\hline \multirow[t]{6}{*}{ Project } & Project management & Project team and organization definition \\
\hline & Engineering & Scope of work allocation, scheduling and monitoring \\
\hline & Procurement & Procurement organization and estimated man-hours \\
\hline & Materials management & Post order organization and man-hours \\
\hline & Operational activities & $\begin{array}{l}\text { Operational activities organization and estimated } \\
\text { man-hours }\end{array}$ \\
\hline & Human resources & $\begin{array}{l}\text { HR recruiting program development and } \\
\text { maintenance }\end{array}$ \\
\hline \multirow[t]{9}{*}{ Function } & $\begin{array}{l}\text { Commercial and bid } \\
\text { management }\end{array}$ & Estimator and proposal manager skill setting \\
\hline & Engineering & Methods/codes and regulations knowledge \\
\hline & Project management & PM skills setting \\
\hline & Procurement & Buyer training and development \\
\hline & Material management & Codes and regulations knowledge \\
\hline & Operational activities & Construction personnel skills setting \\
\hline & Human resources & HR recruiting system development and maintenance \\
\hline & Organization & Organizational structures optimization \\
\hline & Assets & Assets personnel skills setting \\
\hline \multirow[t]{5}{*}{ Portfolio } & $\begin{array}{l}\text { Commercial and bid } \\
\text { management }\end{array}$ & Business line optimization \\
\hline & Project management & $\begin{array}{l}\text { Business line projects execution gap and strengths } \\
\text { analysis }\end{array}$ \\
\hline & Engineering & Engineering make or buy decision making \\
\hline & Operational activities & Operational activities make or buy decision \\
\hline & Business planning and $\mathrm{M} \& \mathrm{~A}$ & $\begin{array}{l}\text { Elaborating business plans for new ventures with } \\
\text { potential partners }\end{array}$ \\
\hline \multirow[t]{9}{*}{ Enterprise } & $\begin{array}{l}\text { Commercial and bid } \\
\text { management }\end{array}$ & Business line profitability \\
\hline & Project management & Execution centers selection and monitoring \\
\hline & Engineering & Engineering centers selection and monitoring \\
\hline & Procurement & Procurement centers localization decision making \\
\hline & Material management & Post order centers localization decision making \\
\hline & Operational activities & Partnership selection management \\
\hline & Human resources & $\begin{array}{l}\text { Long-range planning, development and circulation of } \\
\text { critical resources }\end{array}$ \\
\hline & Internal audit & $\begin{array}{l}\text { The market's perception of the company, } \\
\text { its performance and communication activities } \\
\text { gap analysis and corrective actions }\end{array}$ \\
\hline & Strategy and development & $\begin{array}{l}\text { Potential business in the geographic areas interest } \\
\text { monitoring }\end{array}$ \\
\hline
\end{tabular}

to limit similar events in the future, using capabilities at higher organisational level, e.g. "lesson learnt identification and management", to modify and improve the capability "project vendor list analysis ad qualification plan", inserting stricter vendors' requirements. Eventually the company could also use this know-how to generate a new procurement strategy through the capability "supply chain management strategy definition" (big supplier, networked or vertical relationship, etc.).

Hence, different risk control options were identified in order to manage impacts at all levels, as summarized in Table VI. 


\begin{tabular}{|c|c|c|c|c|c|}
\hline $\begin{array}{l}\text { Management } \\
\text { level }\end{array}$ & Process & Capability & $\begin{array}{l}\text { Reactive } \\
\text { approach }\end{array}$ & $\begin{array}{l}\text { Proactive } \\
\text { approach }\end{array}$ & \\
\hline \multirow[t]{3}{*}{ Project } & Operational activities & Change order identification & $x$ & $x$ & \\
\hline & Procurement & $\begin{array}{l}\text { General terms and condition follow- } \\
\text { up for the project procurement } \\
\text { activities }\end{array}$ & $x$ & & \\
\hline & Project management & Project planning activities & & $\mathrm{x}$ & \\
\hline \multirow[t]{2}{*}{ Functions } & Legal & $\begin{array}{l}\text { Assistance to manage disputes } \\
\text { arising in the contractual } \\
\text { relationship with client and/or } \\
\text { partner and/or subcontractor }\end{array}$ & $x$ & & \\
\hline & Procurement & $\begin{array}{l}\text { Project vendor list analysis ad } \\
\text { qualification plan }\end{array}$ & & $\mathrm{x}$ & \\
\hline \multirow[t]{2}{*}{ Portfolio } & $\begin{array}{l}\text { Commercial and } \\
\text { bid management }\end{array}$ & Client relationship management & $x$ & & $\begin{array}{r}\text { Table VI. } \\
\text { Alternative risk }\end{array}$ \\
\hline & Procurement & $\begin{array}{l}\text { Procurement progress and } \\
\text { deviation management }\end{array}$ & & $\mathrm{x}$ & $\begin{array}{l}\text { mitigation strategies for } \\
\text { the risk: "project delay }\end{array}$ \\
\hline \multirow[t]{2}{*}{ Enterprise } & Internal audit & $\begin{array}{l}\text { Lesson learnt identification and } \\
\text { management }\end{array}$ & & $\mathrm{x}$ & $\begin{array}{l}\text { due to a supplying of } \\
\text { components, which do }\end{array}$ \\
\hline & Procurement & $\begin{array}{l}\text { Supply chain management strategy } \\
\text { definition }\end{array}$ & & $\mathrm{X}$ & $\begin{array}{l}\text { not respect the design } \\
\text { requirements" }\end{array}$ \\
\hline
\end{tabular}

This third case shows how a company could face the same risk with radically different approaches, more or less proactive, and by involving different organisational levels. Different approaches and risk mitigation strategies are adequately represented by specific combinations of RM capabilities and the activation of different resilience mechanisms, as supported by the adoption of the multi-level "Spring model".

Nevertheless, the role and contribution of the third risk propagation/control mechanism could be fully appreciated when a simulation approach is implemented, in order to better evaluate trade-offs between different risk-control options among management levels. Indeed, project portfolio and enterprise organisational levels are those where it is possible to assess and solve possible saturations of available RM capabilities, to avoid the recurrent use of less effective capabilities or, on the other side, to promote the most effective ones to mitigate similar risks affecting different projects or similar delocalised functional units (e.g. engineering units, yards).

\section{Conclusions}

The paper aimed to propose a model to deploy ERM ideas at operational levels in project-based organization, exploiting the concept of capabilities to create a shared language, transversal to different organizational levels. Indeed, in the ERM literature, most of the existing papers look at ERM in the light of the corporate governance debate, emphasising its role as an external accountability device (Power, 2004; 2007; Kajuter et al., 2007; Spira and Page, 2003). In the project management literature, instead, researchers focused on risk management as a tool to deal with unexpected events at project/portfolio level often through a contingency approach (Cagno et al., 2008; Project Management Institute (PMI), 2004; Pennock and Haimes, 2002; Raz and Michael, 2001). 
The proposed model aimed to make a connection between these two spheres, exploiting the concept of capabilities (Collis, 1994; Teece, 1997) that are looked at as a means whereby companies can manage their risk (O'Reily and Tushman, 2007).

In this light, the proposed model has relevant implications from both the academic and managerial perspective. From an academic standpoint, the paper aims to contribute to the recent stream of research on ERM systems. In this field, most works proposing models and approaches to implement ERM have been developed by practitioners or professional associations, whilst the paper represents an attempt to deal with this problem with a conceptual tool, that is well grounded in the strategic management literature (i.e. resource based view of the organization and its more recent developments concerned with the concept of capabilities).

From a managerial standpoint, this approach can support managers at different organizational levels to manage risks/opportunities in a integrated and holistic way. In particular, the model can be used for a retrospective analysis, to study the risk management strategies adopted to respond to unexpected events, pinpointing the limitations and areas for improvement of existing mitigation mechanisms. In this connection, the model can support the identification of potential inconsistence between unexpected events and the capabilities used to manage them. For instance, relying on the capability analysis, it is possible to pinpoint the existence of a polarization in the risk response strategies, in terms of focus on a subset of the available event response strategies, and misalignment of the used risk/opportunity response strategies. Second, the model can be used prospectively, as a managerial tool, to support operational and strategic decision-making. On the one hand, it can help the identification of recurrent events and paths potentially available to manage them (in terms of capabilities/combinations of capabilities), besides the ones that are generally used. On the other hand, it can contribute to identify those events that could be managed more effectively at different levels across the organisation (e.g. project portfolio).

In the end, we discuss the main limitations of the present work and the areas for future development. So far, the operational model has been applied on a single real case; besides, the analysis was based on qualitative data (interviews and documental analysis). Instead, future research should test the predictive potential of the proposed model through simulation tools, adopting a quantitative approach. This could also allow the comparison of different managerial paths (i.e. action plans that adopt different sets of capabilities) to respond to a specific event (i.e. identify the more effective/efficient solution).

A further potentially interesting issue is the integration of the proposed model with the planning and control system. First, company's targets, at present, are considered input factors of the proposed model (i.e. planning and risk management are sequential processes, though the output of ERM can influence targets defined in the first stage). Future research could attempt to integrate planning and RM, to consider targets and risks simultaneously. Second, the model could also be extended through the identification of a set of key risk indicators, for each organizational level, to contemporary monitor risk exposure and organization's performances. 


\section{Notes}

1. The Committee of Sponsoring Organizations of the Treadway Commission (COSO) is a joint initiative of the five private sector organizations: the American Accounting Association (AAA), the American Institute of Certified Public Accountants (AICPA), Financial Executives International (FEI), The Institute of Internal Auditors (IIA), and the National Association of Accountants (now the Institute of Management Accountants (IMA)).

2. EVA is a synthetic measure of the company's ability to create profits and it is calculated as operating profit $-($ WACC $\times$ invested capital).

\section{References}

AIRMIC (2002), A Risk Management Standard, The Association Insurance and Risk Managers, London.

Ambrosini, V. and Bowman, C. (2009), "What are dynamic capabilities and are they a useful construct in strategic management?", International Journal of Management Reviews, Vol. 11 No. 1, pp. 29-49.

Amit, R. and Schoemaker, P.J. (1993), "Strategic assets and organizational rent", Strategic Management Journal, Vol. 14, pp. 33-46.

Arena, M., Arnaboldi, M. and Azzone, G. (2010), "The organizational dynamics of enterprise risk management", Accounting Organization and Society, Vol. 35, pp. 659-675.

Arena, M., Arnaboldi, M. and Azzone, G. (2011), "Is enterprise risk management real?", Journal of Risk Research, Vol. 14 No. 7, pp. 779-797.

Bowling, B.M. and Rieger, L. (2005), "Success factors for implementing enterprise risk management", Bank Accounting and Finance, Vol. 18 No. 3, pp. 21-26.

Bruce, R. (2005), "Swift message on risk management", Accountancy, 22 April.

Cagno, E., Caron, F. and Mancini, M. (2008), "Dynamic analysis of project risk", International Journal of Risk Assessment and Management, Vol. 10 Nos 1/2, pp. 70-87.

Collier, P.M., Berry, A.J. and Burke, G.T. (2007), Risk and Management Accounting, CIMA Publishing, London.

Collis, D. (1994), "Research note: how valuable are organizational capabilities?", Strategic Management Journal, Vol. 15, pp. 143-152.

COSO (2004), Enterprise Risk Management - Integrated Framework, Committee of Sponsoring Organizations, New York, NY.

Deloach, J.W. (2000), Enterprise-wide Risk Management. Strategies for Linking Risk and Opportunities, Prentice-Hall, London.

Eisenhardt, K.M. and Martin, M. (2000), "Dynamic capabilities: what are they?", Strategic Management Journal, Vol. 21, pp. 1105-1121.

FRC (2005), Internal Control: Revised Guidance for Directors on the Combined Code, Financial Reporting Council, available at: www.frc.org.uk

Glendon, I. and McKenna, E. (1995), Human Safety and Risk Management, Chapman \& Hall, London.

Hamel, G. and Valikangas, L. (2003), “The quest for resilience”, Harvard Business Review, Vol. 81 No. 9, pp. 52-65.

Harrington, S.E., Niehaus, G. and Risko, K.J. (2002), "Enterprise risk management: the case of united grain growers", Journal of Applied Corporate Finance, Vol. 14 No. 4, pp. 71-81. 
Helfat, C. and Lieberman, M. (2002), "The birth of capabilities: market entry and the importance of pre-history", Industrial and Corporate Change, Vol. 11 No. 4, pp. 725-760.

Hiles, A. and Barnes, P. (2001), The Definitive Handbook of Business Continuity Management, Wiley, Chichester.

Hill, C.W.L. and Jones, G.R. (1992), Strategic Management Theory, An Integrated Approach, Houghton Mifflin Company, Boston, MA.

Hitt, M.A., Dacin, M.T., Levitas, E., Arregle, J.L. and Borza, A. (2000), "Partner selection in merging and developed market contexts: resource-based and organizational learning perspectives", Academy of Management Journal, Vol. 43, pp. 449-467.

Kajüter, P., Linsley, P. and Woods, M. (2007), International Risk Management: Systems, Internal Control and Corporate Governance: International Perspectives, CIMA Publishing, London.

King, A. and Tucci, C. (2002), "Incumbent entry into the new market niches: the role of experience and managerial choice in the creation of dynamic capabilities", Management Science, Vol. 48, pp. 171-186.

Miller, K.D. (1998), "Economic exposure and integrated risk management", Strategic Management Journal, Vol. 19 No. 5, pp. 497-514.

Muralidhar, K. (2010), "Enterprise risk management in the middle-east oil industry: an empirical investigation across GCC countries", International Journal of Energy Sector Management, Vol. 4 No. 1, pp. 59-86.

Olson, D. and Wu, D. (2007), Enterprise Risk Management, World Scientific Publishing, Singapore.

O'Reily, C. and Tushman, M. (2007), Ambidexterity as a Dynamic Capability: Resolving the Innovator's Dilemma, Harvard Business School, Boston, MA.

Pennock, M.J. and Haimes, Y.Y. (2002), "Principles and guidelines for project risk management", Systems Engineering, Vol. 5 No. 2, pp. 89-108.

PMI (2004), Project Management Body of Knowledge Guide Book, Project Management Institute, Newtown Square, PA.

Porter, M.E. (1986), Competition in Global Industries, Harvard Business School Press, Boston, MA.

Power, M. (2004), The Risk Management of Everything, Demos, London.

Power, M. (2007), Organized Uncertainty Designing a World of Risk Management, Oxford University Press, Oxford.

Prahalad, C. and Hamel, G. (1990), "The core competence of the corporation", Harvard Business Review, Vol. 68, pp. 79-91.

Raz, T. and Michael, E. (2001), "Use and benefits of tools for project risk management", International Journal of Project Management, Vol. 19 No. 1, pp. 9-17.

Sheff, Y. (2005), The Resilient Enterprise: Overcoming Vulnerability for Competitive Advantage, MIT Press Books, Cambridge, MA.

Spira, L.F. and Page, M. (2003), "Risk management: the reinvention of internal control and the changing role of internal audit”, Accounting, Auditing and Accountability Journal, Vol. 16 No. 4, pp. 640-661.

Stenzel, J. (2007), CIO Best Practices, Wiley, Hoboken, NJ.

Teece, D.J. (2007), "Explicating dynamic capabilities: the nature and microfoundations of (sustainable) enterprise performance”, Strategic Management Journal, Vol. 28 No. 13, pp. 1319-1350.

Teece, D.J., Pisano, G. and Shuen, A. (1997), "Dynamic capabilities and strategic management", Strategic Management Journal, Vol. 18 No. 7, pp. 509-533. 
Trkman, P. and McCormack, K. (2009), "Supply chain risk in turbulent environments a conceptual model for managing supply chain network risk", International Journal of Production Economics, Vol. 119 No. 2, pp. 247-258.

Välikangas, L. (2010), The Resilient Organization: How Adaptive Cultures Thrive Even When Strategy Fails, McGraw Hill Professional, New York, NY.

Woods, M. (2007), "Linking risk management to strategic controls: a case study of Tesco plc", International Journal of Risk Assessment and Management, Vol. 7 No. 8, pp. 1074-1088.

Yin, R. (1994), Case Study Research: Design and Methods, Sage, Beverly Hills, CA.

Zwikael, O. and Sadeh, A. (2007), "Planning effort as an effective risk management tool", Journal of Operation Management, Vol. 25, pp. 755-767.

\section{Further reading}

Van Thuyet, N., Ogunlana, S.O. and Dey, P.K. (2007), "Risk management in oil and gas construction projects in Vietnam", International Journal of Energy Sector Management, Vol. 1 No. 2, pp. 175-194. 